\title{
INSTYTUCJA MAŁŻEŃSTWA W STAROŻYTNYM PRAWODAWSTWIE KOŚCIELNYM (III-VI w.)
}

Droga analizy źródeł kościelnych do VI stulecia wazcznie można uzyskać obraz pierwotnej dyscypliny ościelnej w odntesieniu do instytucji małzeństwa. Do końca III w. miarodajne pozostaja tutaj zarówno dokumenty o charakterze ściśle prawnym/np. "Didache" czy"List św.Klemensa Rzymskiego do Koryntian", jak rómniez inne, o charakterze ogólnym/np. "Pasterz" Hermasa/. Począwszy od IV w. źródłami ustawodawstwa sensu stricto zaczynaja być sobory i synody, papieźe oraz cesarze. Znaczny wpływ na treść kościelnych norm prawnych w zakresie małzeństwa wywarły równiez pisma 0jców Kościoła ${ }^{1}$.

\section{Okres do IV w.}

Ważnym źródłem poznania problematyki małżeństwa w pierwotnym Kościele jest, powstałe ok. $218 \mathrm{r}$. w izymie, dzieło śr.Hipolita pt. "Traditio Apostolica"2. Jego rozdział XV traktuje o tych, stórzy mają przyjąć wiarę poprzez słuchanie słowa Bożego. Kandydaci do katechumenatu winni być postawieni przed doktorami, aby odpowiedzieć, dlaczego decyduja siz̨ na nawrócenie. M.in. kandydata pyta

1 Zob. m.in.: F.Stanghellini, Il diritto matrimoniale nelle opere dei Padri della Chiesa, "Archivio giuridico" 84/1910/ 77-140; L.Anné, La conclusion du mariage dans la tradition et le droit de l'Eglise latine jusqu'au VIe siecle, "Ephemerides theologicae Lovanienses" 11/1945/513-550; tenże, Les rites des fiangailles et la donation pour cause de mariage sous le Bas-Emp1re, Louvain 1941; G.Violardo, Il pensiero giuridico di S.Girolamo, Milano 1937; Tenże, Appunti sul diritto matrimoniale in S.Ambrogio, S.Ambrogio nel XVI centenario della nascitá, Milano $1940,485-512$.

2 Traditio Apostolica, ed. B.Botte/Hippolyte de Rome, La Tradition Apostolique d apres les ancienes versions. Introduction, traduction et notes, Paris $1968 /=11$ bis. 
sie o to, czy posiada kobietę/kobieta zaś mężcyznę/, czy jest molnym czy też niewolnikiem. Małżonkom poleca się, aby byli wzajemnie z siebie zadowoleni, nieżonatych zaś poucza się, aby nie współżyi z kobietami, lecz zawarli małzeństwo według prawa, bądź też pozostali w stanie bezżennym ${ }^{3}$. Użycie tam zwrotu "sumere mulierem secundum legem" zdaje się świadczyć o uznawaniu za waźne małżeństwa zawartego stosownie do przepisów prawa świeckiego, do którego przestrzegania chrześcijanie są zobowiązani.

Rozdział XVI traktuje o badaniu kandydata do katechumenatu w przedmiocie zawodu i pełnionych przezeń zaję́. Kto wykonuje określone zawody, np. rzeźbiarza, malarza, aktora, musi je porzucić, inaczej bowiem nie może przyjąć wiary. Szczególny wymóg stawia się tutaj wobec żyjących w konkubinacie:

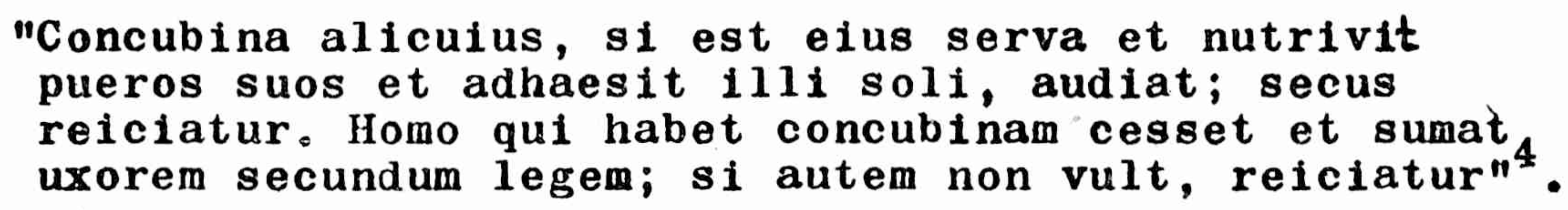

Kto posiada więc konkubinę, powinien ją porzucić 1 pojąć zonę według prawa, w przeciwnym wypadku nie może być dopuszczony do katechumenatu. Tu równiéz chodzi o prawo rzyıskie, wymagające dla legalności małżeństwa connubium ${ }^{5}$.

Pierwsza część przytoczonego tekstu stanowi jednak wyjątek od zasady trzymania się prawa świeckiego, głoszonej przez Hipolita. Chodzi bowiem o przypadek niewolnicy związanej z dęzczyzną wolnym. W myśl prawa rzymskiego, taki związek nie mógł istnieć jako małżeń-

3 Traditio Apostolica 15, SCh 11 bis, 68-70: "Interrogentur autem de vita eorum qualis sit: an sit ei mulier vel an sit servus. Et si quis est servus alicuius fidelis et dominus eius ei permittit, audiat verbum ... "Si autem aliquis habet mulierem, vel mulier virum, doceantur contenti esse vir muliere et mulier viro. Si quis autem non vivit cum muliere, doceatur non fornicari, sed sumere mulierem secundum legem, vel manere sicut est".

4 Traditio Apostolica 16, SCh 11 bis, 74.

5 Por. E.Volterra, Matrimonio /diritto romano/. Enciclopedia del diritto, t.25, Milano 1975, 733-735. 
stwo, lecz jako konkubinat ${ }^{6}$. Tymczasem autor "Traditio Apostolica" zmierza niedwuznacznie do uznania waźności takiego związku, jeśli konkubina-niewolnica zajmie się własnymi dziećmi i będzie utrzymywała intymne stosunki jedynie ze swoim waścicielem. W takim stanie rzeczy może rozpocząć katechumenat. Tego rodzaju bowiem zwiazzek, zdaje się pośrednio motywować Hipolit, zachowuje swoja godność 1 wymaga dochowania wierności. Właśnie wierność, jak również monógamia oraz wychowanie dzieci stanowią wym ujeciu fundamentalne wymogi związku małżeńskiego. W ten sposób próbuje się w "Traditio Apostolica" pogodzić wymogi moralności chrześcijańskiej z zakazami prawa rzymskiego.

Również duża wartość poznawcza w interesującej nas problematyce przedstawiaja powstałe w Syri w 1.poI. III w. "Didascalia Apostolorum", których pierwsze rozdziały moźna uznać za rodzaj malego kodeksu rodzinnego. W myśl nieznanego autora, relacje pomįdzy małżonkami powinny opierać się na wajemnej miłości. Oddanie męza wobec żony powinno być całkowite ${ }^{\boldsymbol{T}}$, analogicznie, żona powinna bez reszty kochać męża ${ }^{8}$.

W Innym fragmencie tego zbioru autor zachęca męzów:

"Itaque, cum naturalia profluunt uxoribus vestris, nolite convenire illis, sed sustinete eas et, scientes propria membrg esse, diligite sicut proprias animas $[\ldots]^{\prime \prime}$.

Żonom zaś poleca się:

6 Por. A.Montan, Alle origini della disciplina matrimoniale canonica, "Apolitnaris" 54/1981/158-159.

7 Didascalia Apostolorum I 3,1-2, ed. F.X.Funk/Didascalia et Constitutiones Apostolorum, vol. 1t2, Paderbornae 1905/, t.1,8: "Portate ergo, sicut1 servi et P1li1 Doi, invicem; 1 ta ut vir mulierem suam, non ut superbus aut elatus sed benignus sit eiusque manus porrecta ad dandum, ut uxori suae soli suavem se faciat eamque honeste contentam reddat atque id agat, ut ab ea sola ametur neque ab alia".

8 Didascalia Apostolorum I 8,1-2, Funk, t.1,20-22: "Muller vero subiecta sit viro suo, quoniam vir caput est mulieris, et caput viri in via iustitiae incedentis est christus[...]time virum tuum, o mulier, et reverere eum, eique soli placere stude et parata esto ei servire".

9 Didascalia Apostolorum VI 22,6, Funk t.1,378. 


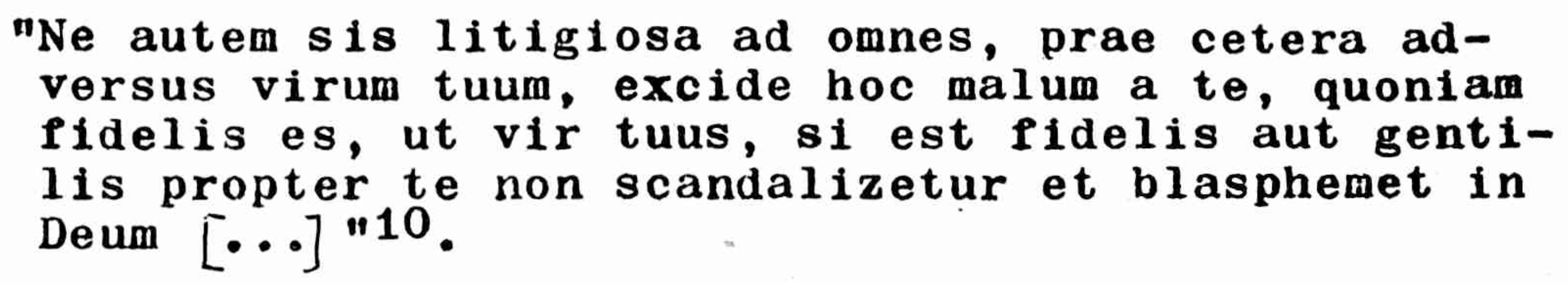

Miłość zatem, jak widać, stanowi zdaniem autora zbioru podstawę wszelkich wzajemnych odniesień małżonków.

W innym zbiorze, "Konstytucjach Apostolskich" z ok. 400 r., podejmuje się - rozdziale VIII - sprawe konkubinatu. Autor podaje rozstrzygnięcie w ducinu omówionej wyżej dyspozycji św.Hipolita. Tak więc niewolnice - konkubinę danego poganina, związana tylko z nim, można dopuścić do katechumenatu. Jeżeli jednak utrzymuje intymne kontakty także z innymi, powinna być odsunięta od przyjęcia wiary. Gdy natomiast chrześcijanin posiada konkubinę będącą niewolnicą, powinien ją porzucié i zawrzeć związek małzeński według prawa. Jeślıby jednak była wolna, ma ją przyjąć jako legalną żonę, w przeciwnym wypadku nie może być dopuszczony do katechumenatu ${ }^{11}$.

Cytowany zbiór wydaje się wykluczać, przynajmniej implicite, związek wolnego mężczyzny z niewolnioą. Przejawia się tutaj trudność ówczesnego Kościoła w rozdzieleniu małżéstwa religijnego od cywilnego?

\section{Okres od IV do VI}

Plerwsze sobory i synody wniosły nowe elementy do pierwotnej dyscypliny wakresie małżéstwa.

Wiele dyspozycji w interesującym nas przedmiocie wydał synod

10 Didascalia Apostolorum 1 10,1, Funk t.1,28.

11 Constitutiones Apostolorum VIII 32,12-13, Funk t. 1,537: "Concubina cuiuspiam infidelis mancipium, illi soli dedita, admittatur; si autem etiam cum alis petulanter agit, reiciatur. Fidelis qui habet concubinam, si servam, desinat et legitime ducat uxorem, si liberam, eam in uxorem legitimam accipiat; si nolit, reiciatur. Si vero fidelis femina coniuncta sit cum servo aut desinat aut reiciatur ".

12 Por. J.Gaudemet, La décision du Callixte en matière de mariage, w: Société et mariage, Strasbourg 1980, 114. 
w Elwirze /295-303 r./. Na uwage zasługuje najpierw kan. 61, który zakazuje zawierania związku małżeńskiego pomiędzy mężczyzną

i siostra jego zmarłej żony, z uwagi na pierwszy stopień powinowactwa w linii bocznej ${ }^{13}$.

Niedozwolone jest także małżenstwo - jako związek kazirodczy - pomiędzy mężczyzną i córkaz zrodzoną z piérwszego zwiazzku źony ${ }^{14}$. Chodzi więc o pierwszy stopień powinowactwa w linii prostej.

Kan. 67 zawiera jeszcze inny zakaz, choć niezbyt jasny:

"Prohilendum, ne qua fidelis vel catechumena aut comatos aut viros cinerarios habeant. Quaecumque hoc fecerint, a communione arceantur"15. Wydaje się, że dyspozycja ta odnosi się do kooiet chrześcijanek lub odbywajazcych katechumenat, zalsazując im brania za męźów tych, których działalność była społecznie potępiona ${ }^{16}$.

Kan. 15 zakazuje małżeństwa pomiędzy strona chrześcijańskaz 1 pogańską ${ }^{17}$. Jest charakterystyczne, że zakaz ten nie został zaopatrzony żadnz sankcja karnaz. Prawdopodobnie chodzi tutaj, zdaniem J.Gaudemeta, bardziej o radę niż o formalny zakaz, a to z uwagi na trudności w aplikowaniu tej zasady w szczególnym kontekście społecznym ${ }^{18}$.

Poza tym, zalrazem synodu zostały objąte małżéstwa pomiędzy dziewczętani katolickimi i heretykami lub Żydami. Kan. 16 wychodzi

13 Concilium Eliberitanum can. 61, ed. J.Vives - T.Marin Marinez G.Martinez Dies, Concilios Visigoticos e IIispano-romanos; $t .1$, Barcellona-Madrid 1968, 12: "Si quis post obitum uxoris suae sororem eius duxerit, et ipsa fuerit ficelis, quinquennium a communione placuit abstineri, nisi forte velocius dari pacem necessitas coegerit infirmitatis".

14 Concilium Eliberitanum can. 66, Concilios Visigoticos 13: "Si quis privignam suam duxerit in uxorem, eo quod sit incestus, placuit nec in finem dandam esse communionem".

15 Concilium Eliberitanum can. 67, Concilios Visigoticos 13.

16 J.Gaudemet, Le concile d'Elvire, DHGE XV 330; Montan, art.cyt., 164.

17 Concilium Eliberitanum can. 15, Concilios Visigoticos 4: "Propter copiain puellarum gentilibus minime in matrimonio dandae sunt virgines Christianae, ne aetas in flore tumens in adulteriun aninae resolvatur".

18 J.Gaudemet, Le concile d'Elvire, DHGE XV 331. 
bowiem z założenia, iż pomięazy wierzacym a niewierzacym nie może Istnieć żadna prawdziwa wspólnota ${ }^{19}$. codzicom wiz̨c dziewcząt, którzy przekraczaja wspomniany zakaz i zezwalaja na małżeństwa mieszane córek grozi sankcja wykluczenia na okres 5 lat od komunii św. Jeszcze większą kara, bo wykluczenia od komunii św. na całe życie, grozi rodzicom kan. 17 w przypadku wydania córki za kapłana pogański ego 20

Odniesienie w obydwu przypadkach sankcji karnej do rodziców pozostaje zgodne ze strukturą patriarchalną ówczesnej społeczności, która w sprawie małżeństwa dzieci przyznawała znaczna rolę rodzicom, szczególnie ojcu ${ }^{21}$. Zakazy byíy podyktowane obawą o utratę wiary małżonki katoliokiej.

W kan. 65 synodu, w nawiazzaniu do prawa rzymskiego zawierającego nakaz odsunięcia od siebie przez duchownego żony winnej cudzołóstwa ${ }^{22}$, sankcjonuje się wspomniane przestępstwo karą wieczystego wykluczenia od komunii św. 23 .

Także w dyspozycji kan. 70 widać wpływ prawa rzymskiego, tyn razen w odniesieniu do mężcyzn świeckich w analogicznej do poprzedniej sytuacji $i^{24}$. Wopomniany w tekscie okres czasu pozostawania kobiety winnej cudzołóstwa w domu męża/aliquo tempore/ jest prawdopodobnie

19 Concilium Eliberitanum can. 16, Concilios Visigoticos s.4: "Haeretici si se transferre noluerint ad ecclesiam catholicam, nec ipsis catholicas dandas esse puellas; sed neque Iudaeis neque haereticis dare placuit, eo quod nulla possit esse societas fideli cum infideli. Si contra interdictum fecerint parentes, abstineri per quinquennium placet".

20 Concilium Eliberitanum can. 17, Concilios Visigoticos 4-5: "Si qui forte sacerdotibus idolorum filias suas iunxerint, placuit nec in finem eis landam esse communionem".

21 Por. P.Lombardia, Los matrimonios mixtos en el concilio de Elvira, "Anuario de historia del derecho espanol" 24/1954/ 543-558.

22 E:Volterra, Istituzioni del diritto privato romano, Roma 1974 , 672 przyp. 3 oraz 650 .

23 Concilium Eliberitanum can. 65, Concilios Visigoticos 13: "Si cuius clerici uxor fuerit moechata et scierit eam maritus suus moechari et non eam statim proiecerit, nec in finem accipiat communionem, ne ab his qui exemplum bonae conversationis esse debent, ab eis videantur scelerum magisteria procedere".

24 Concilium Eliberitanum can. 70, Concilios Visigoticos 13: "Si cum conscientia mariti uxor fuerit moechata, placuit nec in inem dandam ei esse communionem. $S_{i}$ vero eam reliquerit, post decem annos accipiat communionem, si eam quum sciret adulteram aliquo 
tak1 sam, jaki prawo rzymskie przyznawało męzowi do niewnoszenia skarg1 o cudzołóstwo 25 .

o niewierności małżeńskiej traktuje ponadto wiele innych kanonów synodu ${ }^{26}$. Najbardziej charakterystyczny jest tu kan. 69, który przewiduje sankcję karną zarówno za cudzołóstwo kobiety, jak i męźczyzny, co stanowi novum 27 .

Gdy mowa o sankcjach, należy zaznaczyć, że mają one tutaj charakter pokutny. Synod nie stawia bowiem problemu waźności związków małżeńskich, mimo tego rodzajusankcji kanonicznych. Nie można więc tutaj mówić o ustawach unieważniających, a więc o przeszkodach małżeńskich sensu stricto ${ }^{28}$.

Synod Arles /314 r./ przyjizł dwa kanony, które dotyczą małżeństwa. Kan. $11 / 10 /$ odnosi się do sprawy powtórnego zwiazzku małżeńskiego młodych mężczyzn, którzy odsunęli od siebie żony winne cudzołóstwa 29 . Natomiast kan. $12 / 11 /$ dotyczy związków mieszanych 30. W odróżnieniu od analogicznego kan. 15 synodu w Elwirze, kan. 12/11/ synodu w Arles odnosi swoja dyspozycja bezpośrednio do młodych chrześcijanek, które poślubiają pogan, zakazując im takich zwiazzón i stanowiąc, że w wyadku zlekceważenia tego zakazu kobiety takie powinny być odsunięte na pewien czas od komunii św.

Interesujace są dwa kanony synodu w Ancyrze /314 r./. Jeden z nich/kan. 10/ zakazuje małżeństwa diakonom, jeśli przyjmując

tempore in domo sua retinuit".

25 E.Volterra, Istitutioni del diritto ..., dz.cyt., 650; por. Montan, art.cyt., 166 przyp. 67.

26 Por. Concilium Eliberitanum can. $8,9,10,11,47,54,64,65,68,69,70$, 72,78; Sankcje karne są tu zróżnicowane w zależności od tego, po raz który miała miejsce zdrada małźeńska, jak również od okoliczności popełnionego wykroczenia.

27 Por. Concilium Eliberitanum can. 69, Concilios Visigoticos 13.

28 Por. A.Bride, Empêchements de mariage, w: Dictionnaire de droit canonique, 267.

29 Concilium Arelatense can. 11, ed. C.Munier/Concilia Galiae 314506, Turnholti 1963/ = CCL 148,11: "De his qui coniuges suas in adulterio deprehendunt, et idem sunt adulescentes fideles et prohibentur nubere, placuit ut, quantum possit, consilium eis detur ne alias uxores, viventibus etian uxoribus suis licet adulteris, accipiant".

30 Concilium Arelatense can. 12, CC 148,11: "De puellis Pidelibus quae gentilibus iunguntur, placuit ut aliquanto tempore a commu- 
śmlecenia nie ujawnili intencji jego zawarcia, pod kara utraty wykonywanych Punkcji31. Inny zaś/kan. 11/ nakłada obowiazzek zwrócenia prawowitemu narzeczonemu porwanej mu kobiety, nawet jeśli zosta$1 a$ przez porywajacego zgwałcona ${ }^{32}$. Ta ostatnia norma nabiera szczególinego znaczenia, gdy weźm1e się pod uwage instytucję obietnicy małzeństwa, znaną Azj1 Mniejszej w IV wieku.

Równieź synod w Neocezarei/314-319 r./ zawarł w wielu swoich kanonach normy dotyczace umowy małżé́skie.i. Zakazuje więc w kan. 2 kolejnych małżéstw kobiety z dwoma bracmi ${ }^{33}$.

Zakaz odnosi się poza tym do kapłana dotkniętego kara depozycj1. T przypadku zaś dopuszczenia się przezeń cudzołóstwa lub n1erządu, należy - wyśl kan. 1 - zastosować karę ekskomunik1, poddając winnego pokucie ${ }^{34}$. Nie jest to jednak jeszcze przeszkoda małzeńska, lecz zwykła niemnłność połaczenia przyjętych święceń 1 1ch wykonywania.

Kan. 31 kan. 7 zabrantają z kolel kapłanowi uczestntczyć w przyjęciu weselnym tego, kto zawiera po raz drugi małzeństwo ${ }^{35}$. Stanowi to wyraz rygorystycznego ustosunkowania się na Wschodzie wobec powtórnego małzeństwa ${ }^{36}$.

Treszcie kan. 8 synodu poleca kapłanowi odprawić żonę cudzołożną, pod kara utraty powierzonych mu funkcji 37 .

Tażnym stwierdzeniem soboru nicejskiego /325 r./ było uznanie - wbrew tendencjom skrajnie rygorystycznym - wartości małzeństwa oraz godz1wości takiego zwiazku ${ }^{38}$.

nione separentur".

31 Concilium Ancyranum can. 10, od. P.P.Joannou, Font1. Discipline générale antique/IVe-IX $\mathrm{X}^{\mathrm{e}} /, \mathrm{t}, 1,2:$ Les canons des Synodes Particuliers, Grottaferrata 1962 , 64.

32 Concilium Ancyranum can. 11, Joainnou t.1,2, 64-65.

33 Concilium Neocaesariense can. 2, Joannou t.1,2, 70 .

34 Concilium Neocaesariense can. 1, Joannou t.1,2, 75.

35 Concilium Neocaesariense can., 3 et 7 , Joannou $t, 1,2,76$ et 78.

36 Por. M.Humbert, Le remariage à Rema, Milano $1967,317$.

37 Concilium Neocaesariense can. 8, Joannou t.1,2, 78-79.

38 Conctlium. Nicaenum can. 8, ed. P.P.Joannou/Font1. Discipline générale antique, $t .1,1:$ Les canons des conciles oecuméniques Grottaferrata 1962/ s.30: "Haec autem eos prae omnibus scriptis convenit profiteri, quod catholicae et apostolicae ecclesiae dogmata suscipiant et sequantur, id est bigamis se communicare". 
Kolejne sobory 1 synody, zarówno wschodnie, jak 1 zachodnie, przyczyniły się do rozwoju pierwotnego prawa małżeńskiego wościele w okresie od IV do VI wieku. Charakteryzuje się on większą precyzją norm podejmowanych w nowych warunkach doskonalenia się organizacji kościelnej w Cesarstwie Rzymsim i przy jego wsparciu. Ustawodawstwo w dziedzinie małżenstwa, wychodząc naprzeciw codziennym problemom, staje się bardziej szczegółowe. Nie pomija jednak równieź kwestii bardziej zasadniczych, takich jak wierność tradycji, wartość małżenstwa czy jego świętośćc ${ }^{39}$.

Odbyty ok. $350 \mathrm{r}$. synod w Gangrze stanowił przejaw walki z tendencjami dyskwalifikującymi małżeństwo jako formę życia. W kilku kanonach biskupi zaprezentowali waściwy obraz zwiazku małżeńskiego, jak również wypowiedzieli się na temat dziewictwa i wstrzemięźliwości ${ }^{40}$. Małżeństwo zostało ukazane jako godna pochwały forma życia, zwłaszcza w połączeniu z pewnz̨ skromnością, zachowaniem wzajemnej wierności, wychowaniem potomstwa oraz wzajemnaz miłością małżonków.

Synod w Laodycei /343-381 r./ ujawnił z kolei ogromną troskę duszpasterską odnośnie do delikatnej wóvczas kwestii powtórnego małżeństwa. Chodziło o zajęcie stanowiska w tej sprawie w duchu skorygowania spotykanych teorii przesadnie rygorystycznych. Tak więc biskupi uznali prawomocność i godziwość powtórnego małżeństwa, dopuszczając osoby zawierające taki związek do przyjmowania komuni św., jakkolwiek po upływie pewnego czasu, w którym winni oddać się modłom i postom 41 .

Innym ustaleniem synodu było wskazanie tzw. dni zakazanych, w których nie można było zawierać małżeństw. W kan. 52 zaznaczono,

39 Montan, art.cyt., 168-169.

40 Por. Concilium Gangrense can. 1,4,9,10,15,16, epilogus, t.1,2, 89-95, 98-99.

41 Concilium Laodicense can. 1, Joannou t. 1,2, 130: "De his qui secundum ecclesiastican regulam libere ac legitime secundis iuncti sunt nuptiis nec occulte furtum copulae perpetrarunt, oportet, ut parvo tempore transacto vacent orationibus et ieiuniis huiusmodi, quibus etiam iuxta indulgentiam conmunionem reddi decrevinus". 
że zakaz ten obejmuje okres Wielkiego Postu 42 .

Oprócz tego na uwage zasługuja normy odnośnie do zachowania się podczas uroczystości ślubnej ${ }^{43}$, jak również dyspozycje dotyczące małżeństw mieszanych katolików z heretykami. Tego rodzaju związki kan. 31 dopuszczał jedynie wówczas, gdy heretyk był w stanie złożyć obietnicę przyjęcia wiary katolickiej44.

Sformułowanie w tej ostatniej sprawie zostało powtórzone w kan. 14 Sóboru w Chalcedonie /451 r./, przy czym zasade zawierania małżeństw mieszanych - pod wymienionym wyżej warunkiem - ojcowie soborowi rozciągnęi także na związki zawierane z żydami i poganami. Jedynie kantorzy 1 lektorzy zostali wykluczeni od zawierania małzeństw $z$ heretykami 45 .

Waźną dyspozycję zawiera tenże kan. 14 w zakresie obowiązku wychowania po katolicku potomstwa zrodzonego ze zwiazku mieszanego ${ }^{46}$. Poleca mianowicie udzielanie chrztu we wspólnocie katolickiej, a nie heretyckiej.

42 Concilium Laodicense can. 52, Joannou t. 1,2, 151: "Quod non oporteat in quadragesima aut nuptias aut natalicia celebrari".

43 Concilium Laodicense can. 53, Joannou t.1,2, 151: "Quod non oporteat Christianos euntes ad nuptias plaudere vel saltare, sed venerabiliter cenare vel prandere sicut condecet Christianos".

44 Concilium Laodicense can. 31, Joannou t.1,2, 143: "Quod non oporteat cum hereticis universis nuptiarum foedera coelebrare nec eis filios dare vel filias: sed magis accipere, sit tamen promittant se fieri Christianos".

45 Concilium Chalcedonense can. 14, Joannou t.1,1, 80-81: "Quoniam in quibusdam provincils concessum est lectoribus et psalmistis uxores accipere, statuit sancta synodus non licere cuiquam ex his sectae alterius uxorem accipere. Qui vero ex huiusmodi coniugio lam filios susciperunt, si quidem praeventi sunt, ut ex se genitos apud haereticos baptizarent, offerre eos ecclesiae catholicae communioni conveniat, non baptizatos autem non posse ulterius apud haereticos baptizari. Sed neque copulari debet nuptura haeretico, Iudaeo vel pagano, nisi forte promittat se ad ortodoxam fidem orthodoxe copulanda persona transferre. S1 quis autem hanc definitionem sanctae synodi trangressus fuerit. correptioni canonicae subiacebit". 
Warto wspomnieć, iż kan. 15 grozi sankcją ekskomuniki diakonisom, które przyjąw8zy święcenta i sprawując swój urząd przez jakió czas, zawarłyby zwizzek małżeński. Ta sama kara została przepisana także na męźczyznę zawierajęcego małżeństwo z diakonisą ${ }^{47}$. Kan. 16 natomiast ustala identyczną sankcje wobec dziewicy 1 zakonnika, którzy by - po poświęceniu się Bogu w swoich zobowiazzaniach - zawarli związek małżeúski 48 .

Na uwage zasługuja następnie czerpiące obficie, m.in. z synodów wschodnich IV w., "Kanony Apostolskie" porstałe w latach 380400. Wiele z nich porusza problematykę małżeńską. Niektóre postanowienia odnoszz się do kleru. Tak więc jeden z kanonów zakazuje diakonowi, kapłanowi i biskupowi oddalić żonę $z$ motywu pobożności czy religijności, pod karz ekskomuniki, a w razie uporu - depozycji 49. Trzy inne kanony przewidują wykluczenie od przyjęcia święceń tych kandydatów, którzy zawarli powtórne małżeństwo po przyjęciu chrztu, jak również tychl, którzy żyli w konkubinacie, poślubili kobiete, która nie była dziewica lub nie cieszyła się dobra reputacją, lub teź poślubili wasnaz krewną ${ }^{50}$. Tego rodzaju ustawodawstwo zmierzało niewatpliwie do umocnienia celibatu duchownych.

47 Concilium Chalcedonense can. 15, Joannou t.1,1, 81-82: "Diaconissam non ordinandam ante annum quadragesimum et hanc cum summo libramine. Si vero suscipiens manus inpositionem et aliquantum temporis in ministerio permanens semetipsam tradat ad nuptias gratiae Dei contunelian faciens, anathematizetur huiusmodi cum eo, qui illi coniugitur".

48 Concilium Chalcedonense can. 16, Joannou t.1,1, 82: "Virginem quae se Deo Domino consecravit, similiter et monachum, non licere nuptialia iura contranere. Quod si hoc inventi fuerint perpetrantes, excomunicentur". Por. Montan, art.cyt., 171.

49 Canones Sanctorum Apostolorum 5, Joannou t.1,2, 10: "Episcopus aut uxorem propriam nequaquar sub obtentu religionis abiciat. Si veroreiecerit, excommunicetur, sed si perseveraverit deponatur".

50 Canones Sanctorum Apostolorum 17-19, Joannou t.1,2, 16-17. 
Jeden z kanonów zbioru, odrzucając tendencje rygorystyczne potęplone juz przez synod w Gangrze i Laodycei, proklamuje wartośc 1 godziwość małzeństwa jako zwiazku ustanowionego przez Boga ${ }^{51}$.

Liczne synody zaciodnie - prowincjonalne 1 regionalne w Afryce w okresie od IV do VI stulecia, szczególnie w Hipponie /6/ 1 Kartaginie /ok. 30/, nie poświeciły zbyt wiele uwagi interesujacej nas tematyce. Jest to zrozumiałe, gdy weźmie się pod uwage inne róznorodne problemy, któse nurtowały tarntejszy Kościół, takie jak: donatyzm, pelaglanizm, dyscyplina i jednośs kościelna, waźność sakramentów św. 52

Synod w Hipponie z 393 r. zajał sie m.1n. sprawą małzeństwa dziec1 osób duchownych, zakazując im zawieranta tego zwiazku z niewierzacymi, heretykani 1 schizmatykami ${ }^{53}$.

Synod kartagiński odbyty $407 \mathrm{r}$. ustanowit normy dotyczące małzonków zyjących weparacj1, polecając im pozostawanie w niej lub pojednanie oraz zabraniajazc zawarcia nowych zwizzków małzeńskich pod kara pokuty ${ }^{54}$. W takim sformułowaniu kanonukryje sie zasada nierozerwalności małżéstwa. Użyta zaś tutaj terminologia odwołuje się do Pisma $\delta w^{55}$ Ten sam kanon wraża jednocześnie prag-

51 Canones Sanctorum Apostolorum 51, Joannou t.1,2, 35-36: "S1 quis episcopus vel presbyter vel diaconus vel omnino ex sacerdotali numero, a nuptis, carnibus et vino non propter exercitationem, sed propter abominationem abstinet, oblitus quod "omnia valde bona" et quod "masculum et feminam focit Deus hominem", sed blasphemans calumniatur opificium, aut corrigatur aut deponatur et ex ecclesia eiciatur. Similiter et laicus".

52 Por. Montan, art.cyt., 172.

53 Breviarium Hipponense 12, ed. C.Munier/Concilia Africae 345525, Turnholti 1974/ = CCL 149, 37: "Ut gentilibus vel haeret1c1s et schismaticis filil episcoporum vel quorumlibet clericorum matrimonio non coniungantur".

54 Registri ecclesiae Carthaginiensis excerpta 102, CCL 14y, ¿18: "Placuit ut, secundum evangelicam et apostolicam disciplinam, neque dimissus ab uxore, neque dimissa a marito, alteri coniungatur, sed ita maneant, aut sibimet reconcilientur; quod si contempserint, ad paenitentiam redigantur. In qua causa legem Imperialem petendain promulgari".

I Kor $7,10-11$ i Mt 5,32 . 
nienie uczestników synodu, aby władza świecka promulgowała specjalną ustawę o nierozerwalności. małżeństwa. Synod dostrzega więc doniosłość społeczną i prawna nierozerwalności zwiazku małżeńskiego i dlatego postuluje jej potwierdzenie przez prawo świeckie. Widzi także pożytek takiego wsparcia ze strony państwa, m.in. w zakresie egzekwowania wymienionej zasady oraz karania tych, którzy ja naruszyli.

Wiele uwagi poświęcają różnym aspektom małżeństwa - konsolidując prawo w tyra zakresie - synody Galii. Tak więc synod w orleanie z 541 r. zwrócił uwage na konieczność zgody rodzicór na ślub córki stanowiąc, iż nadużywanie własnej woli przez poślubienie dziewczyny wbrew woli jej rodziców ściąga na mężczyznę karę ekskomuniki 56 .

Zbiór "Statuta Ecclesiae Antiqua" z 2. poł. V w. ${ }^{57}$ zawiera w kan. 101 wzmiankę o błogosławieniu małżeństwa przez kapłana ${ }^{58}$, podczas gdy wszystkie pozostałe źródła galijskiego prawa kanonicznego z epoki rzymskiej i epoki Merowingów nie podają żadnych danych na temat tego obrzęur 59 . Kanon nie sankcjonuje obowiazku przyjmowania wspomnianego błogosławieństwa, nie wskazuje także przeszkód uniemożliwiających jego otrzymanie, Zwraca jedynie uwage na powstrzymanie się od pożycia małżéskiego w noc po otrzymaniu błogosławieństwa kapłańskiego przez małżonków. Do rodziców i swatów na-

56 Concilium Aurelianense can. 22, ed. Caroli de Clercq/Concilia Galiae 511-695, Turnholti 1963/ = CCL 148A, 137-138: "Ut nullus per imperium potestatis filiam conpetere audeat alienam, ne coniugium, quod contra parentum voluntate impiae copulatur, velut captivitas iudicetur. Sed si, quod est prohibitum, admittitur, in his, qui perpetraverint, excomunicationis severitas pro modo pontificis inponatur".

57 I.Sugera, Historia źródeł i nauki prawa kanonicznego, Warszawa $1977^{2}, 58-59$.

58 Statuta Ecclesiae antiqua 101, ed. C.Munier/Paris'1960/ s.100: "Sponsus et sponsa, cum benedicendi sunt a sacerdote, a parentibus suis vel a paranymphis offerantur. Qui cum benedictionem acceperint, eadem nocte, pro reverentia ipsius benedictionis, in virginitate maneant".

59 K. Ritzer, Le mariage dans les Rglises chrétiennes du I au XI siècle, Paris 1970, 270-279; Hontan art.cyt., 174. 
leży przedstawianie narzeczonych kapłanowi. Samą prośbę o błogosławieństwo pozostawia się jednak inicjatywie zainteresowanych ${ }^{60}$. Niektóre ustalenia tego samego zbioru odnoszł się do duchownych, zakonników oraz dziewic. Biskupi Galii byli bowien pierwszymi, którzy przyjęli dekretał Innocentego I "Dominus inter", polecający duchownym zachowanie celibatu ${ }^{61}$. Charakterystyczny jest zakaz udzielania święceń duchownemu, który poślubił wdowę lub porzuconą, lub też zawarł dwa razy małżeństwo ${ }^{62}$. Należy dodać, iż kanon ten powtórzył jedynie normę podjętą już na wielu innych synodach ${ }^{63}$. Synod w Orleanie z 538 r. zagroził z kolei ekskomunika duchownemu, który by przyjąwszy dobrowolnie święcenia, zawarł małżeństwo, Ta sama sankcja odnosiła się do kobiety wychodzącej za mąż za takiego mężczyznę. Gdyby zaś duchowny taki popełnił cudzołóstwo, powinien wstąpić do klasztoru 64 .

Ustawodawstwo w odniesieniu do małzeństwa duchownych pozostaje zróźnicowane, w zależności od stopnia święceń oraz odmiennych sytuacji lokalnych. W oparciu o całość norm nie wydaje się jednak, aby status duchownego wiazzał się z absolutnym zakazem małżeństwa.

Gdy chodzi o dziewice poświ z̨cone Bogu, to synod wacon /581-583 r./ zagroził ekskomunika w wypadku zawarcia przez nie związku małżeńskiego, stanowiącego w takim wypadku hańbę ${ }^{65}$. Z takiego samego założenia wyszedł również synod w Lyonie w 583 roku 66 .

Synod diecezjalny odbyty w Sens /561-605 r./ uchwalił zakaz zawierania małżeństwa przez opatów 1 mnichów 67 . Także w kanonach wielu innych synodów znajdujemy podobny zakaz ${ }^{68}$. Jednak tego rodzaju

60 Montan, art.cyt., 174.

61 Por. R.Gryson, Les origines du célibat ecclésiastique du premier au septieme siècle, Gembloux 1970, $190 \mathrm{nn}$.

62 Statuta Ecclesiae antiqua can. 85, Munier 94: "Simili sententiae subiacebit episcopus, si sciens ordinaverit clericum eum qui viduam aut repudiatam uxorem habuit vel secundam".

63 Por. Montan, art.cyt., 175 przyp. 115.

64 Concilium Aurelianense can. 7-8, CCL 148A, 117.

65 Concilium Matisconense can. 12, CCL 148A, 226.

66 Concilium Lugdunense can. 3, CCL 148A, 232.

67 Concilium Autissiodorense can. 24, CCL 148A, 268: "Non licet abbate nec monacho ad nuptias ambulare".

68 Por. synod w Elwirze /kan. 13/, w Ancyrze/kan. 19/, w Toledo z $400 \mathrm{r}$. /kan. 16/, w Orange z $441 \mathrm{r}$. /kan. 17-18/, w Chalcedo- 
zakazy zawierania zwizzzków małżeńskich wbrew ślubom zakonnym nie posiadały sankcji nieważności ${ }^{69}$.

Wiele synodów omawianego okresu wypowiedziało się następnie przeciwko zwizzkom kazirodczym. Na szczególną uwage zasługuje tutaj dyspozycja zawarta w kan. 30 synodu w Epaone z 517 roku ${ }^{70}$. Potepia się w niej zwiazzek mężczyzny z żoną pozostawioną przez jego brata, jak również następujące zwi Łzki: mężczyzny z siostrą własnej żony, pasierba $z$ macochą, mężczyzny z siostrzenica. Normy te powtarzają równiez inne synody ${ }^{71}$.

Synod w Orleanie z $533 \mathrm{r}$. proklanował zakaz rozwiazania małżeństwa w przypadku choroby pod sankcją odsunięcia winnego od przyjmowania komunii św. 72

W pismach papiezy, posiadających początkowo formę listów prywatnych lub listów pasterskich, a następnie w reskryptach, w których biskupi izymu stanowili prawo, znajdujemy szereg ustaleń obejmujących

nie /kan. 16/.

69 J.Gaudemet, $L^{\prime}$ Église dans $l^{\prime}$ empire romain $/ I V^{e}-V^{e}$ siècles/Paris 1958, 202 .

70 Concilium Epaonense can. 30, CCL 145A, 31-32: "Incestis coniunctionibus nihil prorsus veniae reservamus, nisi cum adulterium separatione sanaverint. Incestus vero nec ullo coniugii nomine praevelandus praeter illos, quos vel nominare funestum et, hos esse censenus: si quis relictan fratris, quae paene prius soror exteterat, carnali coniunctione violaverit; si quis frater germanam uxoris suae accipiat; si quis novercan duxerit; si quis consubrinae subrinaeque se societ. Quod ut a praesenti tempore prohibemus, ita ea, quae sunt anterius instituta, non solvemus: si quis relictae avunculi misceatur aut patrui vel privignae concubito polluatur. Sane quibus coniunctio inliceta intedicetur, habebunt ineundi melioris coniugii liberatem".

71 Por. synod w orleanie z $531 \mathrm{r}$. /kan. 18/, w Lyonie z 518-523 r. /kan. 1/, w Clerwont z $535 \mathrm{r}$. /kan. 12/, w Orleanie z $538 \mathrm{r}$. /kan. 11/, w Tours z $575 \mathrm{r}$. /kan. 27/, w Paryżu z 556-573 r. /kan. 4/, w Lyonie z $583 \mathrm{r}$. /kan. 4/, w Macon z $585 \mathrm{r}$. /kan. 18/.

72 Concilium Aurelianense can. 11, CCL 1945A, 100: "Contracta matrimonia accedente infirmitate nulla voluniatis contrarietate solvantur. Quod si qui ex coniugibus fecerint. noverint se communi one privandos". 
wiele aspektót instytucji małzeństwa.

Papiez Syrycjusz /384-398/, w liście do duchowieństwa mediolańskiego mówi o potrzebie obecności kapłana przy zawieraniu małźeństwa ${ }^{73}$. Także w liście z 385 r. do Imeriusza z Tarragony wymieniony biskup rzymsixi zwraca uwage na tę sam̨ okoljiczność ${ }^{74}$. Podkreśla tutaj doniosłość i znaczenie udziału Kościoła w zawieraniu zwi zzków małżeńskich. Jakiekolwiek naruszenie błogosławieństwa kapłańskiego, stwierdza papież, wierni uważajiz za rodzaj świętokradztwa ${ }^{75}$

Posiadajł̨cym święcenia niższe Syrycjusz przỵomina, że nałżeństwo winien błogosławić kapłan ${ }^{76}$. Podobna dyspozycję zawiera także jeden $z$ listów Innocentego I /401-417/77.

Wypada przyporanieć, iż mimo zasygnalizowanych norm pochodzących od papieży, błogosławienie małżeństw przez kapłanów nie było czymś powszechnym ani obowiazzującym, gdy chodzi o pierwszych dziesięć stuleci ${ }^{78}$.

W dekretałach papieskich spotykamy również postanowienia dotyczące wstrzemięźliwości duchownych. Ważny jest tutaj cytowany już list papieża Syrycjusza z $385 \mathrm{roku}^{79}$. Stwierdzając, że wielu

73 Siricius, Epistola 7,3, PL 13, 1171: "Nos sane nuptiarum vota non aspernantes accipimus, quibus velamine intersumus".

74 Siricius, Epistola 1,5, PL 13, 1136-1137: "De coniugali autem velatione requisisti, si desponsatam alii puellar, alter in matrimonium possit accipere. Hoc ne fiat, modis omnibus inhibemus: quia illa benedictio quam nupturae sacerdos imponit, apud fideles cuiusdam sacrilegi instar est, si ulla transgressione violetur".

75 Por. Montan, art.cyt., 178.

76 Siricius, Epistola 1,12-13, PL 13, 1141-1143.

77 Innocentius I, Epistola 2, 7-9, PL 20,473-475.

78 W.M.P18chl, Geschichte des Kirchenrechts, Bd.1, Wien 19602, 235; Dekretał papieża Hormisdasa $/ 514-523 /$, przytoczony w Dekrecie Burcharda z Wormacji, a polecajacy zawieranie małżeństw w sposób publiczny, z błogosławieństwem kapłana/Burchardus Wormaciensis, Dekretorum liber nonus 3, PL 140,816/nie jest autentyczny; Por. litzer, Le mariage, dz.cyt., 235 .

79 Siricius, Epistola 1,8 i-10-11, PL 13, 1138-1141: "Plurimos enim sacerdotes Christi atque levitas, post longa consecrationis suae tempora, tam de coniugibus propriis, quam etiam de turpi coitu sobolem didicimus procreasse, et crimem suum [...] defendere [...] omnes sacerdotes atque levitae insolubili lege constringimur, ut a die ordinationis nostrae, sobrietati ac pudicitiae et corda nostra mancipemus et corpora [...], Quilibet episcopus, presby- 
kapłanów i lewitów posiada dzieci zrodzone nie tylko z prawowitego małżeństwa, lecz także ze związków grzesznych, papież zobowiązuje wszystkich duchownych, aby od dnia przyjętych święceń pamiętali o zobowiazzaniu wstrzemięźliwości i czystości. W przypadkach stwierdzonej niepowściągliwości biskupa, kapłana i diakona winni nie będą mogli liczyć na przebaczenie.

Poza tym, w tym samym liście papiez stanowi, że duchowny, który nie zachowuje absolutnej powściazgliwości cielesnej, winien być wykluczony od przyjęcia kapłaństwa a także diakonatu. Popełniający bigamię nie może otrzymać wyższych święceń; gdy popełnia ją duchowny już wyświ ̨̧cony nie może otrzymać kolejnego stopnia święceń. Duchownemu niższych święceń wolno jest zawrzeć małżeństwo, lecz jedynie z dziewica ${ }^{80}$.

Powyższe dyspozycje powtórzył papież Innocenty I w liście z 404 r. skierowanym do Witryka biskupa liuen, polecając poza tym, aby mnisi, którzy zostają duchownymi, trwali w bezzenności ${ }^{81}$.

Papież Leon Wielki /440-461/, w swoich listach z lat 443-459, przytacza tradycyjne normy odnośnie do niedopuszczania do święceń wyższych bigamistów. Poza tym nakazuje wstrzemięźliwość cielesna jako obowiązkowa - wszystkim sługom ołtarza, łącznie z subdiakonami $^{82}$. Ustawodawstwo tego papieża eksponuje wyraźnie celibat jako formę życia duchownych, nawet tych, którzy posiadali najniższe stopnie święceń. W żadnym jednak tekście stan duchowny nie stanowi zakazu absolutnego, inaczej przeszkody rozrywającej do zawarcia małżeństwa 83 .

Dekretały papieskie przytaczaja jeszcze inne normy, a mianowicie, w odniesieniu do niewolników wojennych. W przypadku tego rodzaju niewolnictwa małżéstwo, według klasycznego prawa rzymskiego,

ter, atque diaconus quod $[\ldots]$ deinceps fuerit talis inventus, iam nunc sibi omner per nos indulgentiae aditum intelligat obseratum: quia ferro necesse est excidantur vulnera, quae fomentorum non senserint medicinam".

80 Siricius, Epistola 1,7-14, PL 13,1138-1144.

81 Innocentius, Epistola 2,12-13, PL 20,475-477.

82 Por. Leo, Epistola 4,2, PL 54,611-613; Epistola 5,3, PL 54,615616; Spistola $12,3-5$, PL 54,648-653.

83 Montan, art.cyt., 179-180. 
rozwiązyało się ipso facto i nie następowało uważnienie mocą prawa powrotu do ojczyzny 84 .

System ten uległ zmianie w dalszej epoce na skutek wpływu idei chrześcijańskich. Niewolnictwo wojenne nie powoduje odtąd rozwiazzania ipso facto małżeństwa, lecz małżonek pozostający w ojczyźnie öbowiazzany był czekać 5 lat na powrót współmałżonka-niewolnika. Dopiero po upływie tego okresu małżonek oczekujłący mógł się uwolnić od więzów małżeńskich i zawrzeć nowe małżeństwo, pod warunkieis jednak braku pewności co do życia współmałżonka zabranego do niewoli 85 .

Ta nowa dyspozycja stanowiła niewątpliwie echo zasady nierozerwalności małżeństwa. Znajdujemy ją m.in. w liście Loona Wielkiego z r. 459, skierowanym do Niceta, biskupa Akwili. Odwołując się do Ewangelii Mateusza /19,6/, papież nadmienia, iż obowiązkiem jest przyjęcie przez kaźdego tego, co do niego należy ${ }^{86}$. W odniesieniu zaś do skutków prawa powrotu do ojczyzny, papieź zauwaza, że jeśl1 sprawach wasności praw 1 rzeczy materialnych obowiązuje - po ustaniu wojny - powrót do stanu właściwego, tym bardziej nalezy to odnieść do zawartych niegdyś zwiłzków małzeńskich ${ }^{87}$. Poleca zatem, aby kobiety, które zawarły podczas wojny małżeństwo, powróciły do pierwszych mężów pod karą ekskomuniki ${ }^{88}$.

\section{Uwagi końcowe}

W oparciu o niektóre tylko źródła uwzględnione w powyższych rozważantach, a ukazujące ściśle określone zagadnienia, można powiedzieć, iż starozytność chrześcijańska nie pozostawiła usystematy-

84 Voltorra, Istituzioni del diritto, dz.cyt., 323-328.

85 Tamźe.

86 Leo, Epistola 159,1 PL 54,1136: "Necesse est ut legitimarum Poedera nuptiarum redintegranda credamus $[\ldots]$ omnique studio procurandum est ut recipiat unusquisque quod proprium est".

87 Por. Leo, Epistola 159,2, PL 54,1137: "Quod si in mancipiis vel in agris, aut etiam in domibus ac possessionibus rite servatur, quanto magis in coniugiorum redintegratione faciendum est, ut quod bellica necessitate turbatum est pacis remedio reformetur?"

88 Montan, art.cyt., 180-181. 
zowanych treści prawnych w przedmiocie małżenstwa. W porównaniu z ówczesnym prawem rzymskim kanoniczna dyscyplina małżeńska wydaje się bardzo fragmentaryczna, niezbyt uwypuklona na tle treści teologicznych i pozbawiona właściwej formalizacji prawnej. Stopniowo jednak nabierała ona coraz bardziej rysów pewnej systematyki.

U podśtaw pierwotnej dyscypliny małżeńskiej Kościoła leżało pojęcie małżeństwa ukazane przez objawienie. Jedność, nierozerwalność i świętość zwiłzku małżeńskiego,coraz lepiej rozumiane, stopniowo ożywiały zastany system prawa, przenikając doń 1 próbując go przekształcić. Na uwagę zasługuje inne niz w epoce klasycznej prawa rzymskiego ujęcie zgody małżeńskiej. Coraz bardziej bowiem przywiązywało się tu wage do poczatkowego ujawnienta wzajemnej woli zawarcia zwiazzku, która to wola rodziła węzeł małżeński, trwający do końca życia jednej ze stron.

Źródła akcentują stosowność zawierania umowy małżeńskiej coram Ecclesia, w obecności kapłana udzielajacego błogosławieństwa, choć z drugiej strony liturgiczna celebracja małżéstwa była całkowicie dobrowòlna, poza małżeństwem duchownych niższych święceń lub osób o nienagannym stylu życia. Małżeństwo jest ukazane jako stan życia, mający swój walor społeczny i przynoszący określoną sytuacje prawna. Na tym tle zrozumiałe jest wydawanie coraz liczniejszych dyspozycji i norm dotyczących małżonków.

Można zatem powiedzieć, iż od poczatku istnienia Kościoła Punkcjonowało w nim prawo małżeńskie, ujawniające się w róznych formach takich jak: zakazy małżeństw w określonych warunkach, stanowienie sankcji karnych w wypadkach cudzołóstwa 1 ponownego zawierania małżéstw, fakultatywne błogosławienie małzonków przez kapłana, rozwiązywanie wypadków spornych.

Ks. Wojciech Góralski - Płock

IL MATRIMONIO NELLA LEGISLAZIONE DELLA CHIESA ANTICA /III-VI s./ /Sommario/

L'analisi delle fonti ecclesiastiche del carattere disciplinare fino al VI $s$. ci permette di osservare un processo di penetrare progressivamente alla sfera d'attivita legislativa della Chiesa la problematica matrimoniale. Un particolare riguardo meritano le norme 
contenute nelle collezioni pseudo-apostoliche, nei canoni dei concili generali e particolari nonchè nei decretali dei papi.

Dall'insieme dei testi analizzati si puó constatare, che la primordiale disciplina matrimoniale canonica appare assai frammentaria e priva di una vera formalizzazione giuridica. Si osserva tuttavia una certa progressiva evoluzione verso una sua sistematizzazione. Secondo le medesime fonti emerge che il matrimonio viene considerato come uno stato di vita, gli è proprio cioè uno stato giuridico. Per questo troviamo nella legislazione diverse disposizioni e norme che toccano gli sposati. Il proprio diritto matrimoniale dell'epoca si manifesta in vari modi: divieti matrimoniali, sanzioni per gli sposi colpevoli, benedizione della Chiesa. 